Przegląd Badań Edukacyjnych Educational Studies Review

ISSN 1895-4308

nr 35 (2/2021), s. 5-31

ORYGINALNE ARTYKUtY BADAWCZE

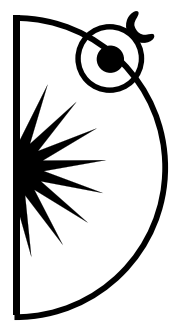

Iwona Myśliwczyk

University of Warmia and Mazury in Olsztyn, Poland

e-mail: iwona.mysliwczyk@uwm.edu.pl

ORCID: https://orcid.org/0000-0002-9826-5642

\title{
Educational Support of a Student with ADHD. An Analysis of Parents' Biographical Experiences
}

http://dx.doi.org/10.12775/PBE.2021.029

\begin{abstract}
:
The aim of this paper is to present the results of a study on the subjective interpretation and the construction of biographies by parents of children with ADHD. The research was driven by insufficient knowledge regarding the definition of the support offered at school to a child with attention deficit hyperactivity disorder among parents and to determine what is important and unique from a parental perspective.

The presented studies were constructivist, interpretative studies using the biographical method. Narrative interviews were conducted with parents of children with ADHD living in Poland. Reconstruction of their parental experiences allowed an understanding of their individual feelings and experiences, which showed "the truth" about the educational support provided to a child. The aim of the studies was a reconstruction of the narrative and an analysis of the subjective meanings which parents give to the educational support that is offered to their children at school. The central thesis took the form of a question: How did parents interpret their own experiences related to educational support given at school to a child with ADHD?

The analysis of the narration shows different parental experiences regarding the educational support received. The reality reconstructed by examined parents is complex and consists of hope and expectations, but also doubts, powerlessness and helplessness. Some parts of the narration are poignant, sorrowful and rife with feelings of loneliness, which is a consequence of misunderstanding a specific child's needs. The other parts of the narrative
\end{abstract}


are dominated by happiness and joy caused by the support that a student received and its effects. By speaking about the help which was received at school, the parents expose their personal feelings towards that event, and they show their individual interpretation of the reality that they experienced. They give subjective meaning to a narrative that they feel is significant.

Keywords: qualitative research, specific educational needs, psychomotor hyperactivity, child's difficulties at school, educational support.

\section{Introduction}

Educational support in the context of special needs pedagogy is implemented on two levels: human and institutional. The former refers to "the student's own perception or appreciation of the learning support provided by those directly involved in their education, i.e. parents, teachers and other students in the class, as well as specialists from the psychological-educational counselling centre" (Gindrich, 2016, pp. 424-425). The second level concerns institutional assistance, i.e. the psychological and pedagogical measures offered to a student with special educational needs, which take the form of a "special" curriculum that takes into account the student's real abilities and needs (Chrzanowska, 1992, p. 192). It can therefore be assumed, after Al-Khamisy, that educational support includes a range of activities aimed at adjusting the way the teaching process is organised and properly implemented, based on the student's needs and the applicable educational standards. The author defines support as "a type of interaction undertaken by one or two parties in a problematic situation in which an informational, emotional or instrumental exchange takes place" (2015, p. 148).

Educational support in Poland in the educational process becomes particularly important with regard to children with special educational needs. The term "student with special educational needs should be understood to include children with a certificate proving the need for special education, as well as those who have difficulties in meeting the standards of the curriculum requirements, resulting from the specificity of their cognitive-perceptual functioning, health and environmental limitations" (Borkowska, 2010, pp. 219-220). The group of students with specific educational needs is heterogeneous. According to legal regulations (MEN, 2017, item 1654), this group includes, among others, a child with attention deficit hyperactivity disorder (the international literature usually uses the abbreviation ADHD). According to the provisions of the Education Law Act (OJ, 2021, item 1082), a student requiring support at school should 
receive effective assistance, taking into account needs and opportunities in order to optimise their education. Within the framework of psychological and pedagogical support for a child with ADHD in the Polish school, Skibska (2011, p. 105) proposes a model containing the following elements:

1. Identifying the individual needs of the student - a multi-specialist team (e.g. a school counsellor, a school psychologist, a speech therapist, a therapist) identifies individual educational needs;

2. Identifying special educational needs - based on the child's diagnosed psychophysical abilities and educational difficulties, the team determines special educational needs of the child with ADHD;

3. Establishing an individual needs record for the student - based on the special educational needs of a child with ADHD, the team creates an individual educational needs record;

4. Developing a support action plan - based on the actions planned and documented in the record, the team develops a support action plan;

5. Application of the arrangements provided for in the record and in the support action plan;

6. Evaluation of measures undertaken - findings included in the record and in the support action plan are subject to evaluation as to whether the provided psychological and pedagogical support has been effective.

An important element of the support for students with special educational needs, as Hallowell and Ratey emphasise, are the psychological-educational counselling centres, which organise therapeutic, educational, corrective-compensatory, logopedic, sociotherapeutic and other activities (2004, pp. 36-37).

It should be stressed that every child in compulsory education in Poland, according to the regulations of the Education Law Act (the basic legal act regulating the operation of schools), has the right to receive support in development and learning in accordance with their individual developmental and educational needs (OJ 2021, item 1082). Children with ADHD belong to a group of students who particularly require to be provided with special conditions in the learning process that would match their individual abilities and needs. Compared to their peers, they demonstrate developmental, behavioural and cognitive difficulties in terms of motor hyperactivity, impulsivity and attention deficits (Borkowska \& Domańska, 2006, pp. 179-180). They are characterised by behavioural disorders, including emotional disorders, which result in difficulties in assimilating and respecting school norms and rules. Consequently, they display aggressive, socially unacceptable and destructive behaviour (Gołubiew-Konieczna, 2016, p. 168). The focus of psychological and pedagogical support is therefore 
on providing equal educational opportunities for this group of students. It is the aim of the educational facility in which the students are placed to provide effective assistance with respect to their identified needs (Borkowska, 2010, p. 219). The representatives of this institution, together with a group of specialists, attempt to define the expectations and needs of children with ADHD, as their sense of security, their integration into a group and their level of social acceptance depend on the degree to which those expectations and needs are satisfied (Myśliwczyk, 2010a, p. 119). A failure to address individual needs increases the risk of educational failure, interpersonal problems and behavioural disorders leading to delinquency (Biederman et al., 2006, p. 168).

In the literature, ADHD is defined in different ways, depending on the concepts adopted. Today, according to Wolańczyk et al., the abbreviation ADHD, which stands for "attention deficit hyperactivity disorder", is used worldwide (1999, p. 13). The terms "attention deficit disorder" (ADD) or "hyperkinetic disorder" (HKD) are also used (Faraone, 2003, p. 106). Polanczyk et al., referring to a 1998 report, claimed that regardless of the name applied, it is one of the most extensively studied disorders in medicine (2007, p. 942). This disorder is "a medical diagnosis applied to children and adults with severe cognitive and behavioural difficulties in important aspects of their lives (e.g. in family and personal relationships, at school or at work). These difficulties can be attributed to impulse control problems, hyperactivity and attention deficit disorders" (Cooper \& Ideus, 2001, p. 25). Another definition states that ADHD is a disorder marked by "developmentally inappropriate deficits in attention, impulsivity and motor hyperactivity that persist for more than six months, and whose severity results in significant difficulty functioning in major areas of life" (Hańć, 2009, p. 9), for example at school.

Classic ADHD is manifested by impulsivity, concentration problems or hyperactivity. These are the symptoms that make it difficult for the child to function in the school environment and that cause the most harm, especially in the context of working with and in a group (O'Regan, 2005, p. 33). Because of the annoying symptoms of the disorder, the following problems are reported most frequently when working with a student with ADHD:

- the child is often distracted; has difficulty following instructions in a sequence; does not complete school assignments; does not comply with everyday duties;

- has difficulty organising their work or other activities, is easily distracted by external stimuli, avoids or procrastinates on tasks requiring sustained mental effort, and often forgets routine matters; 
- when asked about something often answers "I don't know" or guesses, loses things needed for work and other activities, cannot sit still - walks around the classroom, swings on a chair or jumps on desks, is constantly on the move - "runs like crazy", is physically hyperactive, regardless of the situation and need;

- is noisy at play, has difficulty playing quietly, rushes to answer before hearing the whole question, has trouble waiting for their turn, often interrupts or disturbs others, is excessively talkative (Turbiarz, 2004, p. 22).

The above-mentioned behaviours of a child with ADHD result in their lack of acceptance from other students and even rejection. Their peers do not understand these behaviours and the hyperactive child cannot explain why they behave in this manner. Teachers who are unaware of the problem tend to take actions which reinforce the negative behaviour and lead to an intensification of the conflict in the classroom or to the complete isolation of the child (Myśliwczyk, 2010b, p. 98).

A student with ADHD does not have very favourable conditions in the school environment for learning and staying in a group. Hallowell and Ratey emphasise that children with attention deficit hyperactivity disorder are often harmed even though they do not differ in intelligence quotient from their peers. The symptoms they demonstrate make it difficult for them to learn, to relate to other students and teachers and to meet the requirements posed by the school. The problems that accompany them take a toll on their psyche as they are continually criticised, reprimanded and misjudged. As a result, they are unable to build a positive and constructive self-image. They have a whole system of defensive reactions in their minds (2004, pp. 62-75).

The difficult situation of a student with ADHD implies that teachers need to be involved in the didactic and educational process and take supportive measures on their part. Acknowledging the child's individual needs and using their potential resulting from their condition can make the school environment a friendly one. A competent teacher will organise activities where the child will meet their need for movement. Such a teacher will involve the child in group activities where they will learn to plan and act calmly and will assign responsible roles and tasks to the child. However, when the child deserves to be punished, it helps if they are removed from their functions rather than isolated from their peers (Więcek, 2013, p. 19). Children with ADHD acquire knowledge, remember information and analyse it in the same manner as their peers. Nevertheless, they require help to adjust their attention processes, to bring out the knowledge 
they possess and to strengthen their motivation and perseverance. They need support to facilitate their learning and make their stay at school enjoyable.

\section{A methodological perspective}

The aim of this paper is to present the results of a study on the subjective interpretation and construction of biographies by parents of children with ADHD. The research was guided by insufficient knowledge of how to support a child with attention deficit hyperactivity disorder at school and a desire to find out the answers to questions relating to what is individual from the parents' perspective. The undertaken studies were grounded in a qualitative, interpretative approach, and the adoption of this research perspective was dictated by the awareness that the studied phenomenon is difficult to be explored in an objective paradigm. The selected methodological orientation is based on the assumption that "the human being has no direct access to the world around him, he cannot grasp reality 'in itself'. The human being participates in the world, experiences it, gives meanings to its elements, using categories applicable in a given community" (Urbaniak-Zając, 2006, p. 216). The material acquired will make it possible to know and understand the social reality constructed by the parents' experience, to discover the meanings given by them to their own feelings and actions, to reveal their unique nature.

The objective of the research was to reconstruct stories and to explore the subjective meanings that parents of children with ADHD attribute to the educational support offered to their children at school. Thus, it was investigated how parents define the psychological, pedagogical and educational activities undertaken in the school environment, what significance they attach to them and how they interpret them in the context of their children's behaviour. The study did not investigate what ADHD is and what its scale is, but how parents experience the collaboration with the school in satisfying their children's educational needs, how they interpret the measures taken by the school, teachers and specialists, how they define their child's stay at school, their relationship with peers and teachers after this support has been provided. Consequently, the answer to the following research question was sought: How do parents interpret their own experience related to the educational support provided to their child with ADHD at school?

The choice of the research topic, set in the context of the everyday life of parents of children with ADHD, their experiences and activities, justified the use of the biographical method. It is assumed that "biographies provide specific knowledge about the individual, their experiences, actions, motivations and 
consequences of these actions, values, ambitions, etc. At the same time, they provide knowledge about the environment of this individual, about the community life forming the various circles of their social participation" (Chodkowska, 2014, p. 131). The biography constructed by individuals themselves is their own, individual and subjective description of their life, in which the authors present themselves, make some kind of judgment on their own life and interpret it (Kijak, 2016, pp. 126-127). Interpretation as an element inherent in experience "reveals the meanings people give to things, matters, events. The effort to know these meanings is the equivalent of understanding the human being, their psyche, consciousness and motives, which is a characteristic feature of humanistic cognition" (Kijak, 2016, pp. 126-127).

As a consequence of applying the biographical method, the researchers used a narrative interview. Contemporary narrative scholars see a narrative as a distinct form of discourse that is "a retrospective construal of meaning, shaping and ordering past experience, a way of understanding one's own and others' actions, organizing events and objects into a sensible whole, associating and seeing the consequences of actions and events over time" (Kubinowski, 2011, p. 167). With a narrative, each research participant has the chance to "tell their own story in their own way, in the way they prefer, using their own style, their own form and their own media" (Gudkova, 2012, p. 119). Narrative interviews were conducted with persons selected according to the purposive sampling principle. Such selection focuses on an important criterion, i.e. whether the research participants experience the phenomenon in question, whether they are interested in understanding its nature and meaning, whether they agree to participate in a long interview, whether they grant the researcher the right to record the course of the interview and whether they agree to publish the data (Moustakas, 2001, p. 132). The key issue here is the selection of elements with a particular characteristic (Bartosz \& Żurko, 2014, p. 26). In the case of this project, investigated subjects were parents of children with ADHD living in Poland. The research was conducted in late 2019 and early 2020 (November-December 2019 and January 2020). For data protection reasons, the following codes have been used: $\mathrm{K}: 1, \mathrm{~K}: 2, \mathrm{~K}: 3, \mathrm{~K}: 4, \mathrm{M}: 5$ (sex: interview number). The respondents were four women aged 36-45 and one man aged 43. All of them live and work in Olsztyn, and three were mothers raising their children as single parents.

The parents selected for the study consented to the interview and its recording. The interviewees were met several times before the interviews were conducted. The meetings were held in private flats and were designed to build a relationship that would allow the research participants to speak freely. The study 
began by asking parents to talk about their experience regarding their child's time at school and the educational support provided. The stories were recorded through transcription and will provide an important description of a conscious experience every time.

\section{Analysis of own research}

The stories told by the interviewees were assumed to be the objectified experience and the experience of the specialists in terms of their own lives. The analysis of biography encompasses "the whole of an individual's history, the entire course of an individual's life in terms of the analysis of typical sequences of events in life and the meanings attributed to these events" and aims to "capture the subjective interpretation of events in a person's life, made by that person themselves" (Dróżka, 2014, p. 217).

The analytical and interpretative process of the obtained empirical material was based on the concept proposed by F. Schütze (2012), which included the following elements: transcription and providing titles for individual interviews, a formal text analysis, a structural description of the narrative, analytical abstraction, contrastive comparison and synthesis. In practice, the researcher often does not follow the phases in a predefined order, as the stages of the analysis are overlapping, making it possible to return to the stages already completed. The analysis of biographical material is thus multi-phased and highly complex, and its essence is to grant the narrator the right to ultimately give meaning and significance to their own lifeline (Ligus, 2009, p. 98).

The parents' narratives can be divided into several thematic threads: shared and varied. They form a picture of the experiences reconstructed by the parents who have assigned individual meanings to them. In the analysed excerpts from the parents' stories, it is possible to identify a category related to the diagnosis, which was a turning point in the lives of the respondents. Obtaining an opinion/ certificate proving that a child has ADHD implied, in the parents' understanding, support on the part of the school. Some respondents did not need an opinion diagnosing ADHD, but it would not have been possible to get support for their child without it. Along with the diagnosis, the parents expected a specialised approach to the child and the behaviours presented by the child. This is exemplified in the following statement by one of the mothers:

K:1: We have been diagnosed [...] well, actually, I didn't really want to know if it was indeed ADHD. It didn't give me a very strong point of reference, but I can 
honestly say that I did it for peace of mind, so that if it was to be confirmed, then the teachers would look at it with a different eye, so that they would know that they have to approach it a little differently, that it wasn't always Dominik's fault [...].

Diagnosis, as understood by the parents, is the beginning of the path towards taking action in asserting the rights of the child and organising support for the child. The absence of an opinion makes it impossible, as the respondent feels, to change the teachers' approach to working with the child and deepens her feeling of helplessness about the whole situation. The opinion confirming that a child has ADHD becomes particularly important as it provides an opportunity to really help the child. The mother is helpless in the face of certain behaviours of her son at school and expects a professional approach from the teachers regarding the needs of her child with ADHD. In the quoted fragment of the narrative, the boy's frustration is apparent, which is also shared by his mother:

$\mathrm{K}: 2:[\ldots]$ A colleague from work told me that Paweł was entitled to this support and, you know, you follow the advice, so I went to the headteacher. She told me that if we did not have a diagnosis, she couldn't do anything. This friend of mine also has a boy with ADHD, but in a different school, and she said that it really depends a lot on the teachers, so that they don't shift everything on us, but want to help. When she told me that I had to have that diagnosis, it was a shock for me. Then you are helpless... because, you know, we were already so tired of the entire situation that we were in despair. Paweł doesn't want to go to school, and he also says all the time that he doesn't like school, he doesn't like his schoolmates or teachers. Actually, I can't remember when he came from school and he wasn't so depressed or heartbroken.

$\mathrm{K}: 2$ : And when this diagnosis is made, it's like the teacher has a responsibility. He needs to know the rules, he needs to know how to work and this teacher needs to follow them as well. [...] I think it is easier for a parent who has a diagnosis to insist on the rights of that child.

The narrative of the father, for whom the diagnosis was the beginning of a path to getting support from the school, is similar. The narrator sees a lot of his son's negative behaviour and is aware that it is a problem for teachers and classmates. He was informed by the school counsellor that any assistance could be provided after obtaining a diagnosis certificate, so he took steps to obtain one: 
M:5: [...] I mean I see a lot of the bad stuff, but I know it's not up to him [...] but in class, it disturbs the others..."

M:5: Arek can be terrible at times. He mouths off, or if he doesn't like something he says it's stupid, if someone irritates him he can kick or insult them. And what to do when such a 10-year-old behaves like this? I believe that the teachers or the other children are tired of him and that's why we needed this diagnosis; otherwise they would have absolutely hated him.

M:5: There was no other way to help Arek. Anyway, the counsellor said that they, as a school, have other possibilities once they get a diagnosis. So we had to begin this journey (laughs).

The diagnosis also provides an explanation and an excuse for the child's behaviour. The narrator then became confident that the undesirable behaviours were not the result of parental insufficiency but rather a consequence of ADHD. She interpreted the suggestion of the need for family therapy from the school as an accusation, which was an unpleasant experience for her. It may appear that the respondent shifts responsibility to the school once the diagnosis has been obtained:

$\mathrm{K}: 3$ : It was once suggested to me at school to have family therapy, that we supposedly had problems with each other [...]. It was very painful, because it was like being punched in the face... Now I know that his behaviour and mischief are ADHD and not the result of my mistakes, as I was being told. [...] and now the school has to do something.

A similar interpretation of her experience is given by another interviewee. With the diagnosis, she calmed down because she became aware that her child's behaviour was not just the consequence of her parenting. The relief also comes from the narrator's conviction that from the moment of diagnosis, teachers have a responsibility to change and adjust their working methods to meet her child's needs:

$\mathrm{K}: 4:[\ldots]$ but, to be honest, this diagnosis did not scare me so much as it calmed me down. I just could see that it was not the effect of me being a bad mother. Yes, maybe I am not "mother of the year", but [...]. [...], but for me this ADHD diagnosis was a kind of explanation, an understanding of some of his behaviours, because 
I am still learning and in a sense, it was a kind of relief. [...] Well, now the school has some responsibility, because it is clear that they are obliged to work differently with such a child.

The analysis of the narratives reveals that the diagnosis of ADHD was an important motif in the parents' lives. It was the turning point, because with the diagnosis, they could apply for educational support for their children. Based on the narratives, it can be assumed that obtaining an opinion did not change anything in the parents' relationship with and perception of the children, while it was a formal requirement that triggered the educational support procedure. Some authors of the biographies were aware that ADHD symptoms could be a problem for teachers and peers in the classroom. The ADHD opinion/diagnosis provided an opportunity, in the parents' opinion, to "fight" for the child's rights at school and to receive real support for the child. The absence of an opinion made it impossible to take any action, and the authors of the biographies felt that the children needed assistance with their education, as the presented symptoms made it difficult for them to stay at school, interact with peers and teachers or learn.

The absence of an ADHD opinion/certificate resulted in a lack of understanding from teachers about the needs of children with ADHD, which aggravated undesirable behaviour. Children were made scapegoats or were pushed to the margins of class life. Such situations contributed to inadequate self-esteem of the children, low self-worth, dropping out of school, inclusion in pharmacotherapy and even depression. The analysis of the empirical material proves that the teachers' lack of response reinforced the children's aversion towards school and learning. Parents' experiences in this regard were filled with negative emotions: anger, fear, anxiety, and helplessness. These feelings were still alive at the time of the reconstruction, and evoked sadness and tears in the biography bearers. Recalling these experiences was all the more painful since, in the case of some of the narratives, parents had the feeling that they were being accused of bad parenting or lack of interest in their child.

Another category to which the respondents assigned subjective meanings is the definition of educational support. It is mostly interpreted by parents as providing assistance to their child in learning and in the difficulties they experience at school. Parents are placing a lot of hope in teachers, who are not only expected to regard their children more kindly, but also to show professionalism when working with children with special educational needs and to make the child's stay at school more enjoyable. The following statement in- 
dicates the mother's expectation of a change in the attitude of teachers who evaluate her son through the lens of undesirable behaviour. She also hopes that the awareness that her son has ADHD will lead to a kinder attitude towards him, but above all, that no one at school will ever destroy his sense of security again:

$\mathrm{K}: 1:[\ldots]$ It was awful, because he was in the first grade at that time and there was this very unpleasant counsellor, it was the first year, and she wanted to take him to court for demoralisation [...]. She told him this without me, and such a little one got so scared that later he was afraid to go to school".

$\mathrm{K}: 1:[\ldots]$ For me, educational support meant that he would finally have some help from teachers, that teachers would look at him with a different eye and help him a little bit in this school [...] that he would finally be perceived differently and that teachers would not blame him for all the worst.

Educational support is interpreted by the father as other methods of working with the child and meetings with specialists who, with their professional approach, will minimise the consequences of ADHD. The narrator hopes for a change in the teachers' approach towards his son and the behaviours that impede his learning, which are beyond his control:

M:5: I imagined this help in such a way that teachers would use different methods during lessons, that they would use certain techniques to calm him down, I don't know..., that he would attend additional classes with a school counsellor or a psychologist, and that teachers in general would be more tolerant and kinder when they found out that what he was doing was not up to him.

The support for the child is primarily understood as a change in the teachers' current approach to the boy, both in terms of working methods and the evaluation of his achievements. The narrator was convinced that after receiving the opinion proving ADHD, the teaching staff would change their approach in their relationship with the boy and start taking into account his specific learning needs during classes:

K:3: Krzyś's teacher told me that I could apply for help if he was diagnosed with ADHD. At that time, I didn't know yet what it was about, but she explained everything to me... that it was additional classes, more time for tests, that he would be assessed in a different way and that the other teachers would have to adjust a little 
bit to Krzyś's abilities [...] that is, all the teachers would know that he has ADHD and that they have to treat him differently.

Educational support is also defined as extra classes at school, meetings with specialists and other methods of working with the child. The respondent interprets the support primarily as activities organised by the school that will relieve her of the burden of providing support for the boy by herself:

$\mathrm{K}: 2$ : When I received the opinion from the counselling centre about ADHD, I knew that he should be given help in learning, i.e. extra remedial classes or work with a speech therapist or other specialist, different methods of work and such like. This calmed me down a bit, because it is obvious that when we work we do not have much time for all these additional things. [...] which means that this support will be organised at school and that I don't have to run with him to see specialists.

Educational support was similarly interpreted in the subsequent narrative. The mother interprets them as help for her son, but also for herself. So far, both she and her husband had been highly involved in all measures to eliminate the effects of ADHD, but the results were not satisfactory. The constant comments towards the child were not only demotivating, but caused powerlessness, helplessness and a feeling of being left behind. The diagnosis of ADHD brought hope for help and support from the teachers, who until then had remained passive and shifted all responsibility to the interviewee and her husband:

$\mathrm{K}: 4:[\ldots]$ So, for me and my son, it means finally getting some help. Before that, my husband and I were the only ones with this problem, and all I got was information via Librus that Marcel did this or Marcel did that. Of course, it was wrong all the time. We worked with him a lot at home and there were a lot of talks, but when you only get bad information about your son all the time, you know, you're fed up with everything. When we had all the paperwork done, that he has ADHD, and when I took that certificate to the school, the headmaster told me straight away what Marcel's education would look like and what they would do. [...] it was a load off my mind. I just wish it had taken so long for all the paperwork, because Marcel could have been helped much sooner.

Some parents have experienced unpleasant situations at school. These were mainly related to the behaviour of their children, but also to the evaluation and criticism of their parenting methods. Parents felt that a diagnosis of ADHD was 
supposed to contribute to changing their child's situation at school. An ADHD student was to receive support to facilitate their learning, relationships with peers and teachers. It was intended, in the parents' opinion, to help facilitate the child's functioning at school and at home. However, the parents were disappointed because they faced not only questioning of the opinion and its validity, but also criticism of their own parenting methods or the accusation of a lack of interest in their child. The negative evaluation of parents by teachers resonates strongly in the statement quoted below. Parents experienced bitterness because they hoped for real support for their child and themselves, but they were criticised. It can be assumed that the embitterment was all the more acute because the parents spent a lot of time on individual work with their son, which did not produce any improvement. The powerlessness was all the greater because the teachers did not take any steps to make it easier for the child to learn or to help him with the learning process. According to one of the mothers, they followed the established pattern, assuming that no work with the boy would be effective:

$\mathrm{K}: 4$ : I can tell you that the biggest problem is with teachers because they don't accept ADHD as a disease. They believe that it is the fault of parents who have no time for their children and that it is poor child-rearing, that it is the parents' idea and that is where it all comes from. We were devastated and so... I don't know, we felt perhaps disappointed because we thought that once the teachers found out that Marcel had ADHD it would only get better, that they knew best how to work with such children. And here the accusations continued (mother cries) that we were not interested in anything and that it was our fault that he was behaving like this...

K:4: I wish teachers started working with him differently, because I think he's smart, it's just that his ADHD stops him from doing anything. But at present, it has become a routine that he doesn't work during lessons, teachers don't write anything down for him, don't give him any homework, I guess they don't want to help him at all, they just regard him as the fifth wheel. [...] I am very sorry about that because they probably think it won't help anyway, so they don't work with him, but you know, every mother wants the best for her child.

Disappointment also resonates in another life story. The father does not hide his negative emotions with regard to past experiences. He was disappointed with the attitude of teachers who questioned ADHD as a medical condition and, in the respondent's view, were unaware of the nature of this condition and the symptoms associated with it. The narrator was convinced that the teachers' 
attitude towards his son would change when he provided the school with the necessary certificate. However, the situation did not improve and the narrator was left alone with a situation that was unfavourable to his son:

M:5: I was pretty damn angry. Nobody helped us. I was left with all this myself and there were only words spoken that it was such a disease of Western civilisation and that they did not believe in it. What pissed me off was that even teachers who had worked with Arek for a couple of years would say this, but still in conversation with me, they would say 'you know what, Arek is such a rascal'. It seems to me that teachers often don't know, I mean often, every second teacher doesn't know what ADHD is and they don't believe in ADHD. How can they help me? But it was all in anger, because I was sure that if I brought this certificate from the psychiatrist, they would understand and start working with him in a different way.

Another respondent also experienced accusations from teachers. The criticism affected the parents all the more because it came from people who, in the narrator's view, were supposed to help the child learn. The diagnosis of ADHD did not change anything in the behaviour of the teachers, even though the respondent very much hoped for their assistance. Additionally, negative emotions were strengthened by the attitude of the school counsellor, who shouted at the boy and blamed him for conflict situations in the classroom. The school situation was very difficult for the respondent. The reconstruction of these experiences evoked unpleasant emotions:

$\mathrm{K}: 1:[\ldots]$ I faced accusations from teachers, yes, I faced criticism. Actually, it was a tragedy for two years, although it would seem that the people working there were educated. I used to cry a lot then, because those who were supposed to help were the ones who criticised us and Dominik the most. And it was the worst in such situations with the parents, because they all blamed him for everything, that he was naughty, that he was bad. In the first grade, Dominik was transferred from one class to another, because we couldn't stand it all any more [...] later the psychologist suggested individual tuition so that he could relax a bit, because the parents had such an influence on their children that the children's attitude towards him was so humiliating and unpleasant. Even now I have tears in my eyes [...].

The analysis of the narratives shows that providing the school with an opinion/certificate diagnosing ADHD in a child was expected to make a difference in the child's school situation and to result in support in learning and 
in behavioural difficulties. Parents' expectations regarding what they considered to be 'mandatory' support for their child were high. The authors of the biographies hoped for a friendly and professional approach to the child's needs resulting from the condition, i.e. different methods of working, extending the time for independent work, greater understanding and patience, introducing clear rules, involving children in activities to relieve their tension, taking care of relationships with peers, etc. Parents also expected help from a counsellor and psychologist as well as from other teachers who could organise remedial classes. Respondents hoped that their children would enjoy going to school, which would provide them with learning conditions, peace of mind and a sense of security. Some of the narrators were glad to be able to delegate responsibility to the school, as they themselves were already tired of working individually with their children and frustrated by the ineffectiveness of this work. Therefore, they interpreted educational support as providing assistance to the child and to them.

The analysis of the empirical material proves that parents' experiences with regard to the support provided by the school and teachers varied. Some of the narrators interpreted them negatively because they experienced great disappointment. It is clear from the narratives that parents faced criticism, questioning of the opinion, and numerous claims that ADHD is just a made-up concept to justify their parenting inefficiency. The approach of most teachers towards working with children with ADHD has not changed and, from some narratives, it appears that the attack on parents and the child has even intensified. These parents felt powerless and helpless against the school and the teachers working with their children. They experienced the frustration of their children who were unaccepted at school and in the classroom, they felt that their children were treated as objects and pushed to the margins of class life. Such practices resulted in the isolation of children, exacerbation of undesirable behaviour and deterioration of health.

The analysis of the narratives demonstrates that not all interviewees experienced powerlessness, helplessness and disillusionment. The extracts from the story below can be read as the mothers' joy at the support they received. One of the interviewees received help from her son's class teacher who, above all, greatly motivated the mother to obtain a diagnosis of ADHD. The teacher assured the interviewee that this would ensure that specialist help could be provided for the boy. Her attitude gave the author of the biography a sense of security, as she did not judge the boy or his behaviour. The mother placed her trust unreservedly in the teacher, for whom the boy's well-being at school was 
of primary importance. The involvement of this woman and the help provided by other teachers minimised the boy's negative behaviour, which translated into his satisfaction with his stay at school. The boy regained his balance and his position in the class, and his feeling of calmness was also shared by his mother:

K:2: Well, Paweł's class teacher helped me a lot and I knew she wouldn't allow any harm to come to him. Even when things went wrong, she never judged him badly, she always analysed everything, tried to find out why it happened, so she is a teacher with real skills... [...] when I managed to complete all those documents, she told me that she would take care of the rest. In fact, I didn't know what she was going to do, but I knew it would be good.

$\mathrm{K}: 2:[\ldots]$ things have changed, a lot. Before that, I had the impression that it wasn't that they wanted to get rid of him, but that they weren't looking at him and what he could do, how much he could learn, or what he had a problem with. Now it has changed. He is fine now. This school is great. Maybe this diagnosis was really necessary, because without it the teachers can't do anything, but now I'm happy because Paweł has changed, too.

$\mathrm{K}: 2:[\ldots]$ and his class teacher is an angel, so I was more at ease.

$\mathrm{K}: 2$ : Well, I must say that Paweł is lucky to have such a class teacher. She encouraged me to get this diagnosis, but I know that she did it for his good. [...] he gets on better with his classmates, he even goes on trips now, they have rules written on the wall and Paweł has to follow them, so he doesn't get out of hand like he did before, he gets his class tests specially prepared, that is, he has short instructions, and lots of that. He even has a friend who sometimes comes to see him, and this boy is from his class, because earlier Paweł used to cry that nobody wanted to play with him and that the boys ran away from him...

An improvement in the boy's performance at school was also observed by another interviewee. She highlights the high level of competence of the teachers working there and the general openness to 'otherness'. Constructive cooperation with teachers and the development of collaborative solutions greatly helped the boy, who previously could not find his place in the school environment. The boy's stay at school no longer absorbs his mother, who previously felt tired due to her constant availability: 
$\mathrm{K}: 3$ : There is a very high awareness of the problem at school. Not even because there are a lot of children with ADHD, but teachers have been trained here at school on this subject. I have the impression that there is such an acceptance of otherness here in general, and that the teachers really do a lot.

$\mathrm{K}: 3$ : The effects can be seen in his behaviour. I mean he is still very much hyperactive, but the teachers and I have developed rules and we follow them at home as well. Krzyś functions differently now, because before, I had the feeling that the school was too big for him, there was too much stimulation and he was always on the move. I was called in all the time and had to be available, and now they handle it themselves.

Huge support from the school counsellor is also reported by another respondent, but this moment was preceded by a period of "fighting" to help the boy and pushing back attacks from teachers. The situation changed for the better when the school counsellor was changed. A different approach to the boy's problems and the symptoms he presented resulted in recognition of the child's needs. The commitment of the current counsellor to the ADHD student translated into a different approach by the teachers. This brought about a significant improvement in the boy's behaviour and suppression of his dominant symptoms:

$\mathrm{K}: 1$ : The situation changed when they changed the counsellor at school. And that one was really great. She helped a lot, we talked, there was no shouting, no accusations or attacks on us for not having taken care of something. Dominik changed thanks to her, and it was because of her that the teachers became convinced that he really did have ADHD and that it bothered him too.

$\mathrm{K}: 1:[\ldots]$ it looks different now. It may not be outstanding, but at least those comments have been reduced. Now it's more the teachers who ask for help, and before that, it was as if they didn't care, because it was only our problem. [...] Dominik has remedial classes, meetings with the counsellor and the psychologist, and of course, a lot has changed in the classroom. He sits near the teacher's desk and not somewhere in the back; when he starts to get fidgety she sends him to the photocopier or to get the chalk, so it's really changed a lot in the teachers' approach and his hyperactivity and excessive mobility have greatly diminished.

A father who has transferred his son to another school had a similar experience. The stay in the previous school intensified the boy's negative behaviour and caused loneliness in the respondent. The narrator's "fight" for the boy's 
well-being at school ended in failure, as a result of which he felt helpless and powerless in front of his teachers. After his son was diagnosed with depression and spent time in a psychiatric hospital, the interviewee made the decision to change schools. It was motivated by fear for the boy's life. The decision he made was "the best decision ever". The respondent experienced great kindness on the part of the teachers, commitment to the boy's issues and a number of solutions that proved to be beneficial to his son's health. The steps taken at the school have resulted in an improvement in the boy's behaviour and his enjoyment of his stay at the institution:

M:5: I broke down when it turned out he had depression. We put him in a psychiatric hospital and I was afraid that when he came out he would do something to himself. This constant fight with the school exhausted both us and him. We had to do something and we transferred him to another school. It was the best decision and the present school is so friendly and such helpful people work there that it is almost impossible... Arek has changed beyond recognition. We even stopped giving him medication, because it turned out that he could manage without them. [...] it is all thanks to the teachers and their approach to the issue. A lot of understanding, a lot of patience, but most of all such help that all these activities, therapies and what the teachers do help him. I haven’t seen Arek so happy for many years...

The analysis of the empirical material shows parents who were very satisfied with the support and assistance organised at the school. The biography bearers primarily referred to the great commitment on the part of the teachers and specialists who, with their attitude and professional approach, contributed to the recovery of peace and balance in their children. The narrators experienced great kindness and openness to 'otherness'. The full acceptance of the child has resulted in a change in the children's behaviour primarily at school, but also out of school. According to the narratives, the children regained their calmness and enjoyment of their time at school and in the classroom, relationships with peers and teachers improved, undesirable behaviours resulting from the disorder were reduced. The school and the teachers working there ensured that children and parents could feel safe. These parts of the narrative are very joyful and optimistic. With this approach by the teachers, parents no longer feel like intruders, but have a sense of partnership. Cooperation with teachers allows the children to perform better in the educational and upbringing process, thus discovering their potential, developing their skills and building relationships that show that they belong to a group and that their psychological needs are being met. 


\section{Discussion of results and conclusions for pedagogical practice}

The main aim of the research undertaken was to reconstruct the stories and explore the subjective meanings which parents of children with ADHD attributed to the educational support offered to their children in Polish schools. The presented empirical material demonstrated different interpretations of the parental experience of educational support for children with attention deficit hyperactivity disorder. The stories of the children were told by their parents, who gave subjective senses and meanings to their own experiences in this respect. The interviewees emphasised in these narratives the issues that are most important from their perspective. The stories told are similar and diverse in many aspects Reconstructing their own experiences, the parents confronted again different emotions accompanying them at "that" moment of their lives, which due to their intensity, still proved to be vivid.

The first category under analysis was the diagnosis, which represented the turning point in the journey of perceiving a child with ADHD at school and receiving support to adjust the educational programme to their individualised needs. The conclusions of the analysis are confirmed in the research by Myśliwczyk (2010b), which demonstrated the functioning of a child with ADHD in the school environment. The author indicated that the symptoms of the disorder affected the perception of a child who had difficulties with behaviour, learning and peer relationships. Frequently, these children were characterised by a high intelligence quotient, but the uncontrolled symptoms of the disorder had a negative impact on their position in the group, which was also reflected in low grades. The absence of an ADHD diagnosis resulted in the child being perceived as naughty or ill-mannered. In that case, the teachers did not take into account the child's individual learning needs and did not provide them with any support, blaming the parents for the child's bad behaviour at school.

A further analysis of the empirical material focused on the psychological and pedagogical support, in the broadest sense, to be provided to children after an ADHD diagnosis. The interpretation of the majority of parents with regard to this theme focused on teachers who, according to the biographers, did not have adequate competence to work with a child with specific educational needs. Eventually, teachers, in parents' narratives, did not provide support in any aspect of their children's functioning at school. The results of research conducted so far (Al-Khamisy \& Gosk, 2016) indicate that students with ADHD have a very low opinion of teachers' support. The authors highlight the inadequate approach of teachers in providing support at school. This is also raised by Pfiffner (2004), 
who emphasises that the problem lies not only in the teachers' lack of competence to work with the hyperactive child, but also in the school structure. The behaviour of an ADHD student generally disrupts conducting lessons by the teachers and disturbs other students, preventing them from acquiring knowledge. This may be due to the fact that teachers have a huge responsibility and are not always able to adjust the classroom or the lesson to the child's needs and to devote as much time as the child requires. As Marczak (2006) points out, a teacher working with a large number of students can give only $3 \%$ of their attention to each of them. In the case of a hyperactive child, this is certainly not enough. They need about $10-15 \%$ of the teacher's attention in order to work on a comparable level to their peers. As a result of insufficient teacher attention, a child with ADHD receives worse grades than other students in the class with the same abilities. Studies by Kołakowski (2015) as well as Al-Khamisy and Gosk (2016) show that the school performance of children with attention deficit hyperactivity disorder is below their potential. Many children with ADHD (especially those without an opinion/diagnosis) are at risk, repeat a grade, achieve lower results in tests and exams, and " $35 \%$ have difficulty completing high school with sometimes very high intelligence and outstanding abilities which they are unable to put to use" (Al-Khamisy \& Gosk, 2016, p. 352). Constant failures can result in a child with ADHD feeling alone and unhappy, leading to low self-esteem and a sense of low value in the eyes of peers. This can lead to depression, addiction or antisocial personality (Marczak, 2006).

In analysing the experience of parents, it is possible to identify the importance they attached to the educational support given to their children at school. The analysis shows the satisfaction of some parents with the activities offered by the school after receiving an ADHD opinion/certificate. These were specialist activities, since psychological and pedagogical assistance is provided to students in schools by specialists, including speech therapists, vocational counsellors and therapists, and above all by school counsellors and psychologists (Gołubiew-Konieczna, 2016). The narratives of the biography authors reveal that the understanding attitude of teachers and educators is an important element of the support. This is confirmed by the theory that is well established to date, which emphasises that sympathetic teachers who understand the child's problems and who try to help the child with their learning are an invaluable aid to a child with ADHD (Chrzanowska \& Święcicka, 2006). O'Regan (2005) also argues that children with ADHD require different levels of support based on the nature of the disorder they experience or the type of school they attend. This support can be provided by teachers with a high level of knowledge and 
skills and with a positive attitude of the teaching staff towards the specific educational needs of a child with ADHD. The research by Myśliwczyk (2010a) also confirmed that kindness, understanding and assistance from teachers improved children's functioning at school. The empathetic attitude of the teachers resulted in the acceptance of the child and their symptoms by their peers. The children were accepted and supported in their educational journey and, thus, they functioned better in the school environment. Parents were happy that their children were accepted by the school community. This helped the children not only in overcoming school difficulties and in finding their place in the classroom, among their peers. For the interviewed parents, the support of their children at school provided by teachers was of great importance. They were reassured about their child, knowing that the teachers would do everything to make them feel comfortable at school. A positive perception of the child - according to the biography authors - offers support to the parents and their child. It affected the child's further development and had a great influence on their personality.

In the light of numerous studies concerning the issue undertaken (Cooper \& Ideus, 2001; Bobula, 2006; Chrzanowska \& Święcicka, 2006; Hollowell \& Ratey, 2007; Myśliwczyk, 2010b; Herda-Płonka, 2012; Pawlak, 2013; Gołubiew-Konieczna, 2016; Gindrich, 2016; Al-Khamisy \& Gosk, 2016), the research conducted makes it possible to draw cautious conclusions:

- The system of support for the child with ADHD in the Polish school, despite systemic changes, is still inefficient. A child without a diagnosis of attention deficit hyperactivity disorder is not entitled to receive specialist support for development and learning. Teachers do not respect their individual educational needs and abilities, which contributes to the child's isolation in school/class and will aggravate undesirable behaviours resulting from the disorder;

- Levelling the educational chances of a child with specific educational needs is the purpose of psychological-educational assistance, but despite legal regulations, it is still at an insufficient level. Teachers have an insufficient level of knowledge about ADHD or skills with regard to organising support for the child in the learning process. There is a need for training on the nature of the functioning of a child with ADHD and the organisation of an educational programme addressing their needs and abilities;

- The existence of numerous models of work and support for children with ADHD in Poland (Hallowell \& Ratey, 2004; Kołakowski et al., 2007; Skibska, 2011; Al-Khamisy \& Gosk, 2015) does not ensure the opti- 
misation and individualisation of their education. The approach of the school to the needs of a student with ADHD is perhaps a consequence of an inflexible school system that does not take into account the individuality of such a student and does not offer alternatives for ADHD. A child with attention deficit hyperactivity disorder is not treated as a child with special educational needs because ADHD is not recognised as a disability or illness. As a result, the child does not always receive professional help.

- Parents are, in many cases, left on their own in their efforts to support their child at school. They face resistance from headmasters, teachers and specialists against whose attitudes they are powerless and helpless.

The presented conclusions cannot be generalised, but the conducted research does not concern an isolated case and recommends certain changes. Pedagogical practice shows that little has changed with regard to the support of children with ADHD in Polish schools for over a decade. Growing awareness of ADHD, and systemic and legal changes still do not provide children with professional support, which negatively affects their social functioning.

These and other studies show a strong interest in the family with a child suffering from ADHD, in the support provided to the child at school and in various aspects regarding the child's functioning in the school environment. The phenomenon of the ADHD student continues to preoccupy researchers and still leaves many questions unexplained. For this reason, the qualitative research strategy applied in this study gives insight into a fragment of reality from the perspective of the parents' subjective experience. It allows exploring their feelings and individual interpretation of their experiences showing the "truth" about the fragment of the social reality of school in which the child with ADHD functions. The research undertaken does not exhaust the issues concerning the support of the child with ADHD at school. It demonstrates the need to formulate further research problems that allow a fuller understanding of the experience of "being a parent of an ADHD student".

\section{References}

Al-Khamisy, D. (2015). Wsparcie edukacyjne ucznia z nadpobudliwością psychoruchową (ADHD) [Educational Support for the Student with Hyperkinetic Disorder (ADHD)]. Zeszyty Naukowe, 1, 137-151.

Al-Khamisy, D., \& Gosk, U. (2016). Wsparcie społeczne młodzieży z ADHD i młodzieży bez ADHD - badania porównawcze [Social Support of Adolescents With and Without 
ADHD - Comparative Research]. Szkoła Specjalna, 5, 350-361, doi: 10.5604/01378 18X.1229106.

Bartosz, B., \& Żurko, M. (2014). Badanie narracyjne w podejściu interpretatywnym - wskazówka metodologiczna [Narrative Research in an Interpretative Approach - A Methodological Guideline]. Teraźniejszość - Człowiek - Edukacja, 68(4), 19-38.

Biederman, J., Monuteaux, M.C., Mick, E., Spencer, T., Wilens, T.E., Silva, J.M., Snyder, L.E., $\&$ Faraone, S.V. (2006). Young Adult Outcome of Attention Deficit Hyperactivity Disorder: a Controlled 10-year Follow-Up Study. Psychological Medicine, 36, 167-179.

Bobula, S. (2006). Wobec wspótczesności. ADHD dar specyficzny [Confronting the Current Times. ADHD - A Specific Gift]. Kraków: Wydawnictwo św. Stanisława BM.

Borkowska, A. (2010). Organizacja pomocy psychologiczno-pedagogicznej dla uczniów z ADHD w polskim systemie oświatowym [Organisation of Psychological and Pedagogical Assistance for Students with ADHD in the Polish Educational System]. Psychiatria i Psychologia Kliniczna, 10(3), 218-223.

Borkowska, A., \& Domańska, Ł. (2006). Neuropsychologia kliniczna dziecka [Child Clinical Neuropsychology]. Warszawa: Wydawnictwo Naukowe PWN.

Chodkowska, M. (2014). Metoda biograficzna wobec wyzwań pedagogiki specjalnej [The Biographical Method Against the Challenges of Special Pedagogy]. Przeglad Badań Edukacyjnych, 18, 125-142, doi: 10.12775/PBE.2014.010.

Chrzanowska, B., \& Święcicka, J. (2006). Oswoić ADHD. Przewodnik dla rodziców i nauczycieli dzieci nadpobudliwych psychoruchowo [Taming ADHD. A Guide for Parents and Teachers of Psychomotor Hyperactive Children]. Warszawa: Wydawnictwo Difin.

Chrzanowska, I. (2009). Zaniedbane obszary edukacji-pomiędzy pedagogika a pedagogika specjalna. Wybrane zagadnienia [Neglected Areas of Education - Between Pedagogy and Special Education. Selected Issues]. Kraków: Oficyna Wydawnicza Impuls.

Cooper, P., \& Ideus, K. (2001). Zrozumieć dziecko z nadpobudliwościa psychoruchowa. Poradnik dla rodziców i nauczycieli [Attention Deficit/Hyperactivity Disorder. A Practical Guide for Teachers]. Warszawa: Wydawnictwo APS.

Dróżka, W. (2014). Badania biograficzne w pedeutologii. Stan i kierunki ewolucji [Biographical Research in Pedeutology. State and Directions of Evolution]. Przeglad Badań Edukacyjnych, 19, 211-234, doi: 10.12775/PBE.2014.030.

Faraone, S.V., Sierżant, J., Gillberg, C., \& Biederman, J. (2003). The Worldwide Prevalence of ADHD: Is It an American Condition? World Psychiatry, 2(2), 104-113.

Gindrich, P. (2016). Wybrane uwarunkowania wsparcia edukacyjnego młodzieży gimnazjalnej z trudnościami w uczeniu się i zaburzeniami towarzyszącymi [Selected Determi- 
nants of Educational Support for Junior High School Students with Learning Difficulties and Associated Disorders]. In: M. Piorunek, J. Kozielska, \& A. Skowrońska-Pućka (Eds.), Rodzina - młodzież - dziecko. Szkice z teorii i praktyki pomocy psychopedagogicznej i socjalnej [Family - Youth - Child. Sketches from the Theory and Practice of Psychopedagogical and Social Support] (pp. 421-442). Poznań: Wydawnictwo Naukowe UAM.

Gołubiew-Konieczna, M. (2016). Pomoc psychologiczno-pedagogiczna (i nie tylko) a uczniowie o specjalnych potrzebach edukacyjnych w szkołach ogólnodostępnych - aspekty prawne i rozwiązania praktyczne w dobie toczącej się reformy oświatowej [Psychological, Pedagogical (and Other) Support and Students with Special Educational Needs in Public Schools - Legal Aspects and Practical Solutions During the Ongoing Educational Reform]. Niepetnosprawność. Dyskursy Pedagogiki Specjalnej, 22, 162-184.

Gudkova, S. (2012). Wywiad w badaniach jakościowych [Interview in Qualitative Research]. In: D. Jemielniak (Ed.), Badania jakościowe. Metody i narzędzia [Qualitative Research. Methods and Tools] (pp. 111-129). Warszawa: Wydawnictwo Naukowe PWN.

Hańć, T. (2009). Dzieciństwo $i$ dorastanie z ADHD [Childhood and Adolescence with ADHD]. Kraków: Oficyna Wydawnicza Impuls.

Herda-Płonka, K. (2012). Środowisko rodzinne i szkolne wobec zespolu ADHD u dzieci w młodszym wieku szkolnym [Family and School Environment Towards ADHD Syndrome in Early School Age Children]. Kraków: Oficyna Wydawnicza Impuls.

Hallowell, E.M., \& Ratey, J.J. (2004). W świecie ADHD. Nadpobudliwość psychoruchowa z zaburzeniami uwagi u dzieci $i$ dorostych [Driven to Distraction: Recognizing and Coping with Attention Deficit Disorder from Childhood Through Adulthood]. Poznań: Media Rodzina.

Hallowell, E.M., \& Ratey, J.J. (2007). Jak żyć z ADHD. Nadpobudliwość psychoruchowa z zaburzeniami uwagi w świetle najnowszych badań [Delivered from Distraction. Getting the Most out of Life with Attention Deficit Disorder]. Poznań: Media Rodzina.

Kijak, R. (2016). Dorośli z głębszą niepetnosprawnościa intelektualna jako partnerzy, matżonkowie $i$ rodzice [Adults with Deeper Intellectual Disabilities as Partners, Spouses and Parents]. Kraków: Wydawnictwo Naukowe Uniwersytetu Pedagogicznego.

Kołakowski, A. (2015). Zaburzenia zachowania u dzieci. Teoria i praktyka [Behavioural Disorders in Children. Theory and Practice]. Gdańsk: GWP.

Kołakowski, A., Wolańczyk, T., Pisula, A., Skotnicka, M., \& Bryńska, A. (2007). ADHD - zespół nadpobudliwości psychoruchowej. Przewodnik dla rodziców i wychowawców [ADHD - Attention Deficit Hyperactivity Disorder. A Guide for Parents and Educators]. Gdańsk: GWP. 
Kubinowski, D. (2011). Jakościowe badania pedagogiczne [Qualitative Pedagogical Research]. Filozofia - Metodyka - Ewaluacja. Lublin: Wydawnictwo UMCS.

Ligus, R. (2009). Biograficzna tożsamość nauczycieli [Biographical Identity of Teachers]. Wrocław: Wydawnictwo Naukowe DSW.

Marczak, A. (2006). Program pracy z dzieckiem z objawami nadpobudliwości psychoruchowej (ADHD) w przedszkolu lub szkole [Programme of Working with a Child with Attention Deficit Hyperactivity Disorder (ADHD) Symptoms in a Kindergarten or School]. Warszawa: Fraszka Edukacyjna.

Moustakas, C. (2011). Fenomenologiczne metody badań [Phenomenological Research Methods]. Białystok: Wydawnictwo "Trans Humana".

Myśliwczyk, I. (2010a). Dziecko z ADHD w szkole integracyjnej - doświadczenia w narracjach rodziców [A Child with ADHD in an Inclusive School - Experiences in Parents' Narratives]. Niepetnosprawność, 3, 115-125.

Myśliwczyk, I. (2010b). Problemy dziecka z ADHD w świetle analiz biograficznych rodziców [Problems of a Child with ADHD in the Light of Parents' Biographical Analyses]. Warszawa: Wydawnictwo Wyższej Szkoły Pedagogicznej TWP w Warszawie.

O’Regan, F.J. (2005). ADHD. Warszawa: Liber Wydawnictwo.

Pawlak, P. (2013). Dzieci z ADHD i ich rodzeństwo [Children with ADHD and Their Siblings]. Kraków: Oficyna Wydawnicza Impuls.

Pfiffner, L.J. (2004). Wszystko o ADHD [All About ADHD]. Poznań: Wydawnictwo Zysk i S-ka.

Polanczyk, G., Silva de Lima, M., Lessa Horta, B., Biederman, J., \& Rohde, L.A. (2007). The Worldwide Prevalence of ADHD: A Systematic Review and Metaregression Analysis. The American Journal of Psychiatry, 164, 942-948, doi: 10.1176/ajp.2007.164.6.942.

MEN [Ministry of National Education] (2017). Rozporządzenie Ministra Edukacji Narodowej z dnia 9 sierpnia 2017 roku w sprawie zasad udzielania i organizacji pomocy psychologiczno-pedagogicznej w publicznych przedszkolach, szkołach i placówkach [Regulation of the Minister of National Education of 9 August 2017 on the Principles of Providing and Organizing Psychological and Pedagogical Assistance in Public Kindergartens, Schools and Institutions] (OJ 2017, item 1591). Retrieved 20 November 2021 from: https://isap.sejm.gov.pl/isap.nsf/DocDetails.xsp?id=WDU20170001591.

MEN [Ministry of National Education] (2017). Rozporządzenie Ministra Edukacji Narodowej z dnia 24 sierpnia 2017 r. w sprawie organizacji kształcenia oraz warunków i form realizowania specjalnych działań opiekuńczo-wychowawczych w przedszkolach i szkołach specjalnych, zorganizowanych w podmiotach leczniczych i jednostkach pomocy społecznej [Regulation of the Minister of National Education of 24 August 
2017 on the Organisation of Education and Conditions and Forms of Special Care and Educational Activities in Special Kindergartens and Schools Organised in Medical Entities and Social Welfare Units] (OJ 2017, item 1654). Retrieved on 16 February 2021 from: https://isap.sejm.gov.pl/.

Schütze, F. (2012). Analiza biograficzna ugruntowana empirycznie w autobiograficznym wywiadzie narracyjnym. Jak analizować autobiograficzne wywiady narracyjne [Biography Analysis on the Empirical Base of Autobiographical Narratives: How to Analyse Autobiographical Narrative Interviews]. In: K. Kaźmierska (Ed.), Metoda biograficzna w socjologii [The Biographical Method in Sociology] (pp. 141-278). Kraków: NOMOS.

Skibska, J. (2011). Dziecko ze specjalnymi potrzebami edukacyjnymi (SPE) w przedszkolu i szkole - zmiany systemowe [A Child with Special Educational Needs (SEN) in Kindergarten and School - Systemic Changes]. In: I. Adamek, \& Z. Zbróg (Eds.), Dziecko - uczeń a wczesna edukacja [The Child - Student and Early Childhood Education] (pp. 95-108). Kraków: Libron.

Turbiarz, I. (2004). Dziecko nadpobudliwe w szkole [A Hyperactive Child at School]. Remedium, 9, 22-23.

Urbaniak-Zając, D. (2006). W poszukiwaniu kryteriów oceny badań jakościowych [In Search of Criteria for Qualitative Research Evaluation]. In: D. Kubinowski, \& M. Nowak (Eds.), Metodologia pedagogiki zorientowanej humanistycznie [Methodology of Humanist-Oriented Pedagogy] (pp. 209-222). Kraków: Oficyna Wydawnicza Impuls.

Ustawa z dnia 14 grudnia 2016 r. Prawo oświatowe [Educational Law Act of 14 December 2016] (OJ 2021, item 1082). Retrieved on 20 July 2021 from: https://isap.sejm.gov.pl/.

Więcek, R. (2013). Dzieci nadpobudliwe psychoruchowo w wieku przedszkolnym [Psychomotor Hyperactive Preschool Children]. Kraków: Oficyna Wydawnicza Impuls.

Wolańczyk, T., Kołakowski, A., \& Skotnicka, M. (1999). Nadpobudliwość psychoruchowa u dzieci. Prawie wszystko, co chcielibyście wiedzieć [Hyperkinetic Disorder in Children. Almost Everything You Would Want to Know]. Lublin: BiFolium. 